\title{
CASMART 3rd Student Design Challenge to be Featured at SMST2019
}

The Shape Memory and Superelastic Technologies Society (SMST) is teaming with CASMART, the Consortium for the Advancement of Shape Memory Alloy Research and Technology, at the SMST2019 Conference and Exposition in Konstanz, Germany for their 3rd Student Design Challenge.

CASMART, initiated in 2007, has a membership that consists of academics, industry professionals, and government researchers dedicated to promoting the growth and adoption of shape memory alloy (SMA) actuation technologies by achieving new understanding of materials, fostering dissemination of technical knowledge, and facilitating application of that knowledge.

The Student Design Challenge is intended for undergraduate and/or graduate students to consider innovative approaches to developing new materials and hardware using shape memory alloy (SMA) technology. Up to 14 teams with 28 students will have the opportunity to showcase and present their creativity during the CASMART Student Design Challenge. They will present their designs on Thursday, May 16, 2019 at SMST2019.

SMST and CASMART believe in inspiring young minds to pursue science, math, and technology education and careers. SMST is accepting donations to help offset the cost of travel for these students to showcase their materials in Konstanz, Germany. For more information, please visit: http://bit.ly/2RH4Elb and contact John Cerne at john.cerne@asminternational.org. 